\title{
Analiza wyznaczania konsystencji lessów lubelskich na podstawie wyników sondowań statycznych CPT
}

\author{
Krzysztof Nepelski, Agnieszka Lal, Malgorzata Franus \\ Katedra Geotechniki, Wydziat Budownictwa i Architektury, Politechnika Lubelska, \\ e-mail:k.nepelski@pollub.pl,a.lal@pollub.pl,m.franus@pollub.pl
}

Streszczenie: W pracy przedstawiono porównanie wyników badań laboratoryjnych konsystencji gruntów lessowych Lublina z wynikami badań otrzymanych w wyniku sondowań statycznych CPT. Wyznaczone wartości stopni plastyczności porównano z wartościami oszacowanymi z sondowań na podstawie interpretacji z różnych źródeł bibliograficznych. Dodatkowo wyprowadzono własną formułę interpretacyjną. Stwierdzono, że dla podłoża lessowego jako kryterium wydzielenia geotechnicznego odpowiednie jest przyjęcie parametru wiodącego w postaci wartości $q_{c}$, a nie $I_{L}$, które najczęściej jest oznaczane dla gruntów spoistych. Przez wzgląd na możliwość uzyskania bardziej miarodajnych parametrów determinujących nośność podłoża istotne jest rozpoznanie zależności pomiędzy określonymi parametrami.

Słowa kluczowe: sondowanie CPT, lessy, stopień plastyczności, konsystencja, wiodący parametr geotechniczny.

\section{Wprowadzenie}

Tradycyjnie za parametr wiodący dla gruntów spoistych przyjmuje się stopień plastyczności. W większości przypadków określa się go makroskopowo, potwierdzając badaniami laboratoryjnymi na próbkach reprezentatywnych. W związku z tym, że świadomość geotechniczna rośnie, a sondowanie statyczne staje się podstawowym narzędziem badawczym, należy dążyć do wyprowadzania jak największej ilości parametrów bezpośrednio z sondowań. W przeciwieństwie do badań laboratoryjnych, które wykonuje się punktowo, sondowanie jest badaniem ciągłym na głębokości, które wykonuje się w warunkach naturalnych na nienaruszonej strukturze gruntów, ponadto jest szybsze i tańsze.

Przedmiotem badań w niniejszym artykule są utwory lessowe, stanowiące subaeralne osady eoliczne współtworzące podłoże gruntowe Lublina [1]. Geneza powstania gruntów tego typu przez lata stanowiła punkt sporny wśród osób poświęcających się ich badaniom i wciąż jest szeroko dyskutowana, choć dominuje skłonność do przyjęcia poligenetycznych procesów kształtujących właściwości lessów. Powstanie lessów Wyżyny Lubelskiej Malicki [2] przypisuje na okres zlodowacenia środkowo-polskiego, podczas gdy Jahn [3] wiąże je z ostatnim zlodowaceniem polskim (bałtyckim). Lessy powstały wskutek akumulacji eolicznej materiału pyłowego, transportowanego na stosunkowo niewielkie odległości, z czego wynika znaczne zróżnicowanie litofacjalne w różnych obszarach. W efekcie grunty te posiadają specyficzne dla regionu występowania cechy wpływające z kolei na właściwości fizyczne oraz mechaniczne.

Lessy zalegające w Lublinie i jego okolicach składają się głównie z frakcji pyłowej, w której dominuje frakcja $0,05-0,002 \mathrm{~mm}$. Zawartość pozostałych frakcji jest zmienna i zależna od występowania poszczególnych facji bądź poziomów stratygraficznych [4]. 
Głównym budulcem przedmiotowych gruntów jest kwarc, któremu w zmiennych proporcjach towarzyszą skalenie, minerały iłowe i węglan wapnia, przy czym na plastyczność, tarcie oraz osiadanie gruntu ważąco wpływa zawartość minerałów iłowych.

Plastyczność jest charakterystyczną cechą lessów Wyżyny Lubelskiej, na obszarze której występują lessy mało spoiste $\left(w_{p}=1 \div 10\right)$, średnio spoiste $\left(w_{p}=10 \div 20\right)$ oraz zwięzło spoiste $\left(w_{p}=20 \div 30\right)$. Na terenie Lublina najczęściej spotykane są osady mało spoiste w stanie zwartym, bądź też półzwartym, rzadko plastycznym. Stanowią podłoże chętnie wykorzystywane do posadowienia różnorodnych obiektów inżynierskich. Ważnym parametrem fizycznym lessów, często pomijanym w badaniach podłoża jest ich znaczna porowatość, osiągająca nawet 51\%, która wynika z niewielkiej konsolidacji tych osadów, oraz ich mikroporowatości. W przypadku podłoża lessowego o dużej makroporowatości, można mówić o niebezpieczeństwie wystąpienia niekorzystnego zjawiska, jakim jest osiadanie zapadowe mogące powodować szkody budowlane. Szczególnie niefortunne są warunki, w których jednocześnie występuje wysoka porowatość, wilgotność naturalna mniejsza od granicy plastyczności oraz duża zawartość frakcji pyłowej przy niewielkim udziale części koloidalnych [5].

Powyższe właściwości wskazują na konieczność prowadzenia dwutorowych analiz w przypadku wykorzystywania lessów w inżynierii lądowej - zarówno stopnia plastyczności, który decyduje o wytrzymałość gruntu, jak i porowatości, która może znacznie tę wytrzymałość obniżać [6].

Wyznaczenie stopnia plastyczności gruntów lessowych na podstawie sondowań statycznych jest wciąż zagadnieniem niedostatecznie rozpoznanym, a istotną rolę w takich badaniach odgrywa problem regionalności. Jest to powód, aby dla danego regionu oprócz sondowań realizować równolegle prace laboratoryjne. Na podstawie wyników badań należy określić ścieżkę interpretacyjną biorąc pod uwagę dostępne formuły lub wyznaczając nową.

\section{Metodyka badań}

\subsection{Badania polowe}

Badania polowe zrealizowano na terenie Lublina w 21 punktach badawczych. W każdym miejscu wykonano sondowanie statyczne CPT, a następnie w ścisłym sąsiedztwie odwiert badawczy.

Sondowanie statyczne CPT wykonano przy użyciu samojezdnej statycznej sondy Pagani T63-150 o maksymalnym nacisku $150 \mathrm{kN}$. W badaniach zastosowano mechaniczny stożek Begemanna. Stożek wciskano z prędkością $2 \mathrm{~cm} / \mathrm{s}$, a charakterystyki penetracji rejestrowano co $20 \mathrm{~cm}$. Wartości rejestrowane to opór pod podstawą stożka oraz łączny opór podstawy i pobocznicy tulei ciernej. Zastosowane w badaniach stożki charakteryzowały się standardową geometrią: powierzchnia podstawy $-10 \mathrm{~cm}^{2}$, powierzchnia tulei ciernej $-150 \mathrm{~cm}^{2}$, wierzchołkowy kąt stożka $-60^{\circ}$.

W celu wstępnego określenia profilu podłoża, w trakcie wykonywania odwiertów, wykonano analizę makroskopową gruntów. Z wybranych miejsc pobrano do badań laboratoryjnych około 80 reprezentatywnych próbek o naturalnej wilgotności (NW).

Na rysunku 1 przedstawiono przykładowy fragment przekroju geotechnicznego przy punkcie Kraśnicka-4 z widocznym wykresem oporu $q_{c}$ oraz miejscami pobrania próbek do badań laboratoryjnych [7]. 


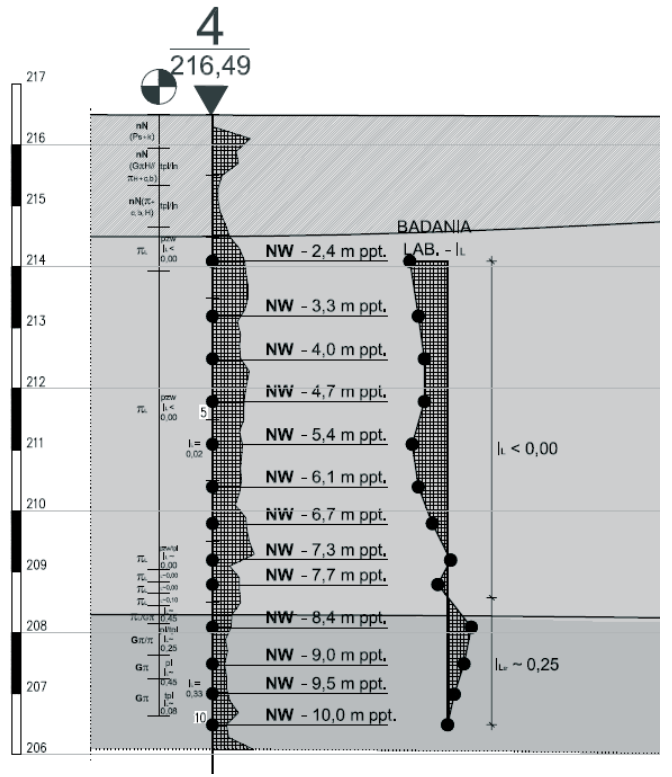

Rys. 1. Fragment przekroju geotechnicznego przy punkcie Kraśnicka-4

Analizę korelacyjną przeprowadzono na podstawie normy PN-B-04452 2002 „Geotechnika. Badania polowe" [8] oraz na podstawie źródeł bibliograficznych [9], [10], [11].

Norma [8] podaje trzy ścieżki interpretacyjne $q_{c}>I_{L}$, w zależności od zawartości frakcji ilastej. Są to równania dotyczące zawartości frakcji iłowej: $f_{i}>30 \%$ (równanie 1), $f_{i}=10 \div 30 \%$ (równanie 2 ) oraz $f_{i}<10 \%$ (równanie 3 ). Zależności wyznaczone ze wzorów są przedstawione na nomogramie (Rys. 2). W analizie wykorzystano zależności 2 i 3.

$$
\begin{aligned}
& I_{L}=0,242-0,427 \log q_{c}(2)-\text { dla gruntów spoistych }-f_{i}>30 \%(1) \\
& I_{L}=0,518-0,653 \log q_{c}(1)-\text { dla gruntów spoistych }-f_{i}=10-30 \% \\
& I_{L}=0,729-0,736 \log q_{c}(2)-\text { dla gruntów spoistych }-f_{i}<10 \%
\end{aligned}
$$

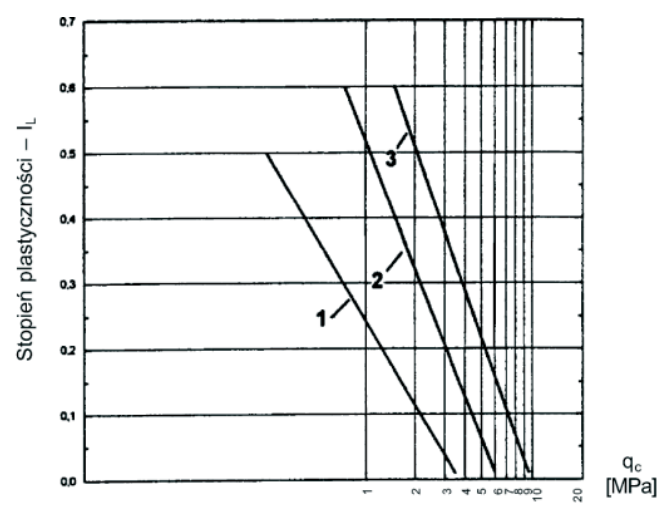

Rys. 2. Nomogram zależności $I_{L}$ od $q_{c}$ wg normy [8]

Wysokiński i współpracownicy w opracowaniu dotyczącym gruntów z terenu całej Polski przedstawiają nomogram do określania stopnia plastyczności $I_{L}[9]$. 


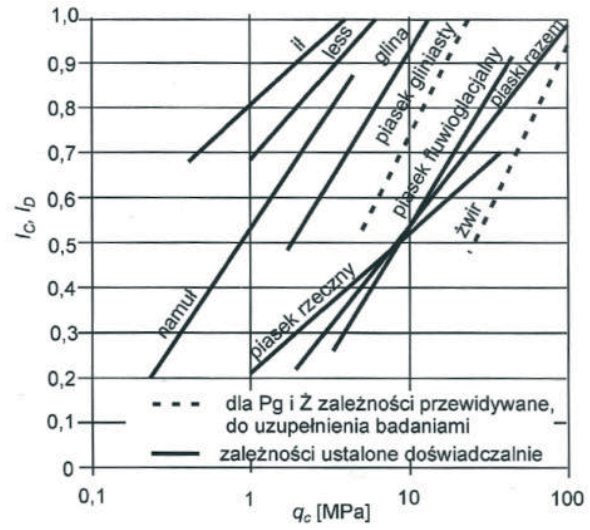

Rys. 3. Nomogram zależności $I_{L}$ od $q_{c}$ dla gruntów polskich wg ITB [9]

Według Wiłuna [10] stopień plastyczności można wyznaczać z nomogramu, który przedstawia zależność $q_{c} / I_{L}$ dla różnych rodzajów gruntów (Rys. 4). Do analizy wybrano zależności nr 2 (gliny spoiste zwięzłe) oraz nr 3 (inne gliny i grunty mało spoiste).

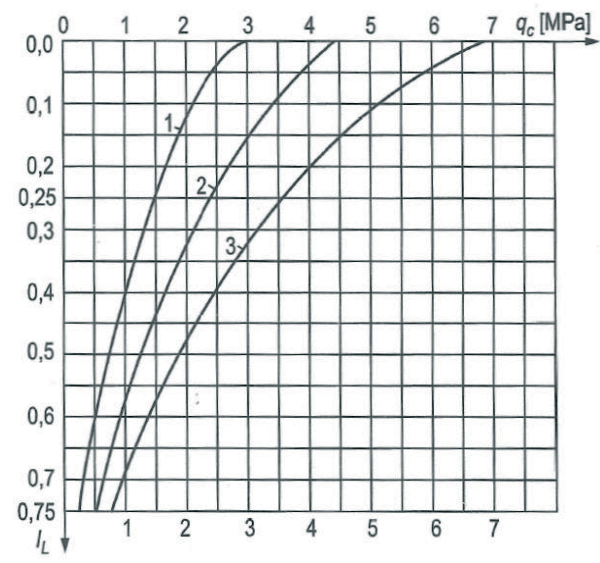

Rys. 4. Nomogram zależności $I_{L}$ od $q_{c}$ wg Wiłuna [10]

Młynarek [11] przedstawia nomogram dla dwóch rodzajów gruntów, tj. dla glin piaszczystych i iłów.

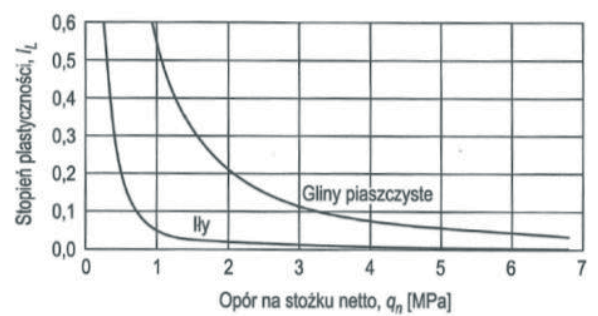

Rys. 5. Nomogram zależności $I_{L}$ od $q_{c}$ wg Młynarka [11]

Do analizy przyjęto zależność jak dla glin piaszczystych (Rys. 5). 


\subsection{Badania laboratoryjne}

Badania laboratoryjne przeprowadzono na próbkach reprezentatywnych, pobranych w trakcie badań polowych z ośmiu miejsc na terenie Lublina. Do oznaczenia wilgotności naturalnej wykorzystano 80 próbek, natomiast dla czternastu gruntów tworzących poszczególne warstwy geotechniczne określano granice ich konsystencji. Granicę płynności wyznaczono przy użyciu aparatu Casagrande'a, natomiast granicę plastyczności określono na podstawie próby wałeczkowania zgodnie z procedurą opisaną w normie [7]. Celem oznaczenia granic konsystencji gruntów tworzących podłoże w rozpatrywanych lokalizacjach w Lublinie było obliczenie wskaźnika plastyczności (Rys. 6).

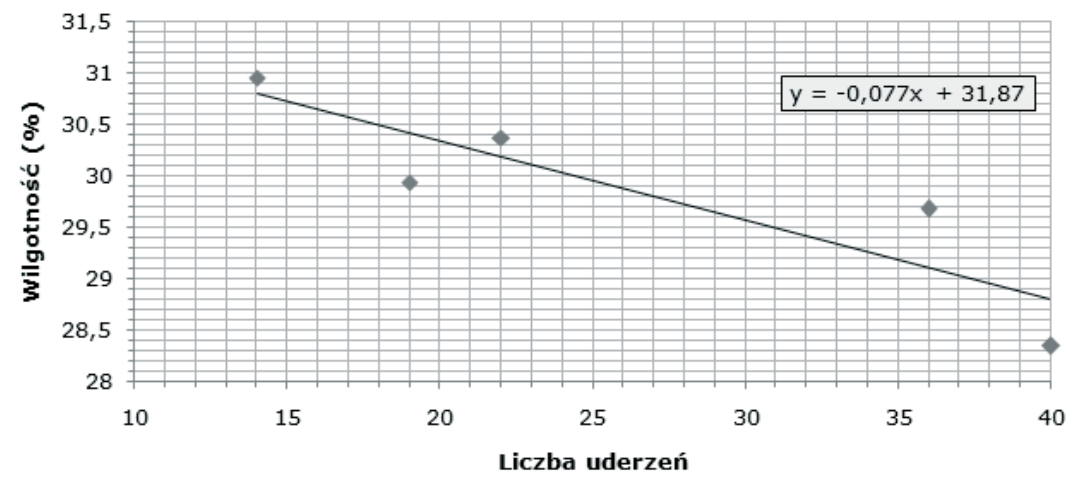

Rys. 6. Wykres z badania granicy płynności metodą Casagrande’a próbki z otworu badawczego nr 5Kraśnicka

Oznaczone wartości granic płynności i plastyczności gruntów pozwoliły na obliczenie ich stopni plastyczności, które następnie poddane zostały próbom korelacji z parametrami oporu pod podstawą stożka $q_{c}$ uzyskanymi w czasie badań polowych sondą CPT. Wykonano także analizę porównawczą wyników badań laboratoryjnych $\mathrm{z}$ wartościami stopni plastyczności $I_{L}$ wyznaczonymi na podstawie korelacji normowych [8] i innych źródeł bibliograficznych [9], [10], [11].

\section{Wyniki badań}

Otrzymane wartości granic płynności $w_{L}$ metodą Casgrande’a, plastyczności $w_{P}$ metodą wałeczkowania oraz wskaźnika plastyczności $I_{P}$ dla poszczególnych gruntów zestawiono w tabeli 1. Wartości średnie oraz odchylenia standardowe prób wskazują na jednorodność właściwości plastycznych w obrębie poszczególnych rodzajów gruntów zalegających w podłożu w wybranych lokalizacjach.

Obliczone wartości stopnia plastyczności gruntów $I_{L}$ zestawiono z wartościami oporów pod podstawą stożka uzyskanymi w czasie sondowań statycznych (Tab. 2). Dodatkowo wartości stopnia plastyczności gruntów $I_{L}$ wyznaczone laboratoryjnie, porównano z wartościami oszacowanymi z sondowania przy użyciu procedur normowych [8] i innych korelacji [9], [10], [11]. Pogrubioną czcionką zaznaczono wyniki zbliżone do laboratoryjnych. Dane zestawione w tabeli 2 poddano dalszej analizie.

W zakresie wyodrębnionych na podstawie stopnia plastyczności warstw geotechnicznych, można zauważyć dużą zmienność oporu pod podstawą stożka $q_{c}$. 
Tabela 1. Zestawienie wyników badań granic konsystencji metodą Casagrande’a

\begin{tabular}{lcccccc}
\hline Lokalizacja & Nr otworu & $\begin{array}{c}\text { Głębokość pobrania próbki } \\
{[\mathrm{mppt}]}\end{array}$ & Rodzaj gruntu & $w_{L}$ & $w_{P}$ & $I_{P}$ \\
\hline Kraśnicka (2) & 5 & 7,5 & glina pylasta & 29,90 & 19,80 & 10,10 \\
\hline Kraśnicka (2) & 5 & 9,0 & glina pylasta & 34,60 & 17,90 & 16,70 \\
\hline Berylowa & 3 & 3,4 & glina pylasta & 39,60 & 20,50 & 19,10 \\
\hline Paganiniego & 1 & 12,4 & glina pylasta & 34,00 & 19,20 & 14,80 \\
\hline Kraśnicka (1) & 4 & 9,5 & glina pylasta & 30,64 & 18,97 & 11,67 \\
\hline & & & Wartości średnie & $\mathbf{3 3 , 7 5}$ & $\mathbf{1 9 , 2 7}$ & $\mathbf{1 4 , 4 7}$ \\
\hline & & & Odchylenie standardowe & 3,86 & 0,97 & 3,66 \\
\hline Kraśnicka (1) & 4 & 5,4 & pył lessowy & 26,83 & 18,47 & 8,36 \\
\hline Cyrkoniowa & 14 & 5,1 & pył lessowy & 26,60 & 20,90 & 5,70 \\
\hline Poligonowa (4) & 7 & 3,5 & pył lessowy & 28,10 & 22,00 & 6,10 \\
\hline Poligonowa (4) & 7 & 5,0 & pył lessowy & 27,30 & 21,00 & 6,30 \\
\hline Berylowa & 1 & 5,0 & pył lessowy & 27,20 & 20,60 & 6,60 \\
\hline Paganiniego & 2 & 9,5 & pył lessowy & 26,10 & 20,30 & 5,80 \\
\hline Paganiniego & 2 & 11,0 & pył & 24,40 & 17,50 & 6,90 \\
\hline Paganiniego & 3 & 11,0 & pył & 20,20 & 15,00 & 5,20 \\
\hline Paganiniego & 1 & 9,8 & pył & 26,20 & 19,40 & 6,80 \\
\hline \multicolumn{1}{r}{} & & & Wartości średnie & $\mathbf{2 5 , 8 8}$ & $\mathbf{1 9 , 4 6}$ & $\mathbf{6 , 4 2}$ \\
\hline & & Odchylenie standardowe & 2,36 & 2,17 & 0,91 \\
\hline
\end{tabular}

Tabela 2. Zestawienie wyników badań laboratoryjnych z odczytami wyników sondowań

\begin{tabular}{|c|c|c|c|c|c|c|c|c|c|}
\hline \multirow{2}{*}{ Dokumentacja } & \multirow{2}{*}{$\begin{array}{c}\text { Nr otworu/ } \\
\text { głębokość } \\
\text { pobrania } \\
{[\mathrm{m} \mathrm{ppt}]}\end{array}$} & \multirow{2}{*}{$I_{\text {Llab }}$} & \multirow{2}{*}{$q_{c}$} & \multicolumn{6}{|c|}{$I_{L}$} \\
\hline & & & & $<10 \%$ & $10-30 \%$ & ITB & Wiłun 2 & Wiłun 3 & Młynarek \\
\hline Kraśnicka (2) & $4 /-5,7$ & $-0,31$ & 5,70 & 0,17 & 0,02 & 0,11 & 0,00 & 0,07 & 0,05 \\
\hline Kraśnicka (2) & $4 /-7,5$ & 0,22 & 3,97 & 0,29 & 0,13 & 0,18 & 0,07 & 0,20 & 0,08 \\
\hline Kraśnicka (2) & $5 /-3,0$ & 0,08 & 5,97 & 0,16 & 0,01 & 0,10 & 0,00 & 0,05 & 0,05 \\
\hline Kraśnicka (2) & $5 /-5,9$ & 0,38 & 4,27 & 0,27 & 0,11 & 0,17 & 0,04 & 0,18 & 0,07 \\
\hline Cyrkoniowa & $2 /-3,0$ & $-0,97$ & 2,93 & 0,40 & 0,22 & 0,23 & 0,19 & 0,33 & 0,13 \\
\hline Cyrkoniowa & $9 /-5,0$ & $-0,47$ & 3,63 & 0,32 & 0,15 & 0,20 & 0,10 & 0,24 & 0,09 \\
\hline Cyrkoniowa & $14 /-3,5$ & $-0,81$ & 6,33 & 0,14 & $-0,01$ & 0,08 & 0,00 & 0,03 & 0,04 \\
\hline Cyrkoniowa & $14 /-5,1$ & $-0,35$ & 4,03 & 0,28 & 0,12 & 0,18 & 0,06 & 0,20 & 0,08 \\
\hline Cyrkoniowa & $14 /-5,7$ & $-0,90$ & 4,02 & 0,28 & 0,12 & 0,18 & 0,07 & 0,20 & 0,08 \\
\hline Poligonowa(4) & $7 /-2,0$ & $-0,32$ & 5,53 & 0,18 & 0,03 & 0,12 & 0,00 & 0,08 & 0,05 \\
\hline Poligonowa(4) & $7 /-3,5$ & $-0,37$ & 7,00 & 0,11 & $-0,03$ & 0,05 & 0,00 & 0,00 & 0,04 \\
\hline Poligonowa(4) & $7 /-5,0$ & $-0,73$ & 3,87 & 0,30 & 0,13 & 0,19 & 0,08 & 0,21 & 0,08 \\
\hline Poligonowa(4) & $7 /-6,5$ & $-1,00$ & 2,82 & 0,40 & 0,22 & 0,23 & 0,19 & 0,33 & 0,13 \\
\hline Poligonowa(4) & $7 /-8,5$ & $-0,88$ & 6,57 & 0,13 & $-0,02$ & 0,07 & 0,00 & 0,02 & 0,04 \\
\hline Berylowa & $1 /-5,0$ & $-2,01$ & 11,03 & $-0,05$ & $-0,17$ & $-0,13$ & 0,00 & 0,00 & 0,02 \\
\hline Berylowa & $6 /-2,8$ & $-2,71$ & 4,23 & 0,27 & 0,11 & 0,17 & 0,05 & 0,18 & 0,07 \\
\hline Berylowa & $6 /-4,0$ & $-1,86$ & 4,53 & 0,25 & 0,09 & 0,16 & 0,00 & 0,16 & 0,07 \\
\hline Berylowa & $6 /-5,5$ & $-2,47$ & 5,53 & 0,18 & 0,03 & 0,12 & 0,00 & 0,08 & 0,05 \\
\hline Paganiniego & $1 /-8,0$ & 0,01 & 4,20 & 0,27 & 0,11 & 0,17 & 0,05 & 0,18 & $\mathbf{0 , 0 7}$ \\
\hline Paganiniego & $1 /-8,5$ & 0,56 & 3,57 & 0,32 & 0,16 & 0,20 & 0,11 & 0,24 & 0,09 \\
\hline Paganiniego & $1 /-9,8$ & 0,45 & 3,40 & 0,34 & 0,17 & 0,21 & 0,12 & 0,26 & 0,10 \\
\hline Paganiniego & $3 /-7,0$ & $-1,13$ & 7,20 & 0,10 & $-0,04$ & 0,05 & 0,00 & 0,00 & 0,03 \\
\hline
\end{tabular}


Analiza wyznaczania konsystencji lessów lubelskich ...

\begin{tabular}{|c|c|c|c|c|c|c|c|c|c|}
\hline \multirow{2}{*}{ Dokumentacja } & \multirow{2}{*}{$\begin{array}{c}\text { Nr otworu/ } \\
\text { głębokość } \\
\text { pobrania } \\
{[\mathrm{m} \mathrm{ppt}]}\end{array}$} & \multirow{2}{*}{$I_{\text {Llab }}$} & \multirow{2}{*}{$q_{c}$} & \multicolumn{6}{|c|}{$I_{L}$} \\
\hline & & & & $<10 \%$ & $10-30 \%$ & ITB & Wiłun 2 & Wiłun 3 & Młynarek \\
\hline Paganiniego & $3 /-9,5$ & $-0,53$ & 5,33 & 0,19 & 0,04 & 0,13 & $\mathbf{0 , 0 0}$ & 0,10 & 0,05 \\
\hline Kraśnicka (1) & $4 /-2,4$ & $-0,63$ & 6,8 & 0,12 & $-0,03$ & 0,06 & $\mathbf{0 , 0 0}$ & $\mathbf{0 , 0 0}$ & 0,04 \\
\hline Kraśnicka (1) & $4 /-3,3$ & $-0,49$ & 6,48 & 0,13 & $-0,01$ & 0,08 & $\mathbf{0 , 0 0}$ & 0,02 & 0,04 \\
\hline Kraśnicka (1) & $4 /-4,0$ & $-0,39$ & 6,70 & 0,12 & $-0,02$ & 0,07 & $\mathbf{0 , 0 0}$ & 0,01 & 0,04 \\
\hline Kraśnicka (1) & $4 /-4,7$ & $-0,38$ & 7,07 & 0,10 & $-0,04$ & 0,05 & $\mathbf{0 , 0 0}$ & $\mathbf{0 , 0 0}$ & 0,04 \\
\hline Kraśnicka (1) & $4 /-5,4$ & $-0,59$ & 6,33 & 0,14 & $-0,01$ & 0,08 & $\mathbf{0 , 0 0}$ & 0,03 & 0,04 \\
\hline Kraśnicka (1) & $4 /-6,1$ & $-0,49$ & 5,95 & 0,16 & $\mathbf{0 , 0 1}$ & 0,10 & $\mathbf{0 , 0 0}$ & 0,06 & 0,05 \\
\hline Kraśnicka (1) & $4 /-6,7$ & $-0,26$ & 7,17 & 0,10 & $-0,04$ & 0,05 & $\mathbf{0 , 0 0}$ & $\mathbf{0 , 0 0}$ & 0,03 \\
\hline Kraśnicka (1) & $4 /-7,3$ & 0,04 & 6,67 & 0,12 & $-0,02$ & $\mathbf{0 , 0 7}$ & 0,00 & 0,01 & 0,04 \\
\hline Kraśnicka (1) & $4 /-7,7$ & $-0,17$ & 5,63 & 0,18 & $\mathbf{0 , 0 3}$ & 0,11 & $\mathbf{0 , 0 0}$ & 0,08 & 0,05 \\
\hline Kraśnicka (1) & $4 /-8,4$ & 0,38 & 3,63 & 0,32 & 0,15 & 0,20 & 0,10 & 0,24 & 0,09 \\
\hline Kraśnicka (1) & $4 /-9,0$ & 0,26 & 3,10 & 0,37 & 0,20 & 0,22 & 0,16 & $\mathbf{0 , 3 0}$ & 0,11 \\
\hline Kraśnicka (1) & $4 /-9,5$ & 0,10 & 3,37 & 0,34 & 0,17 & 0,21 & 0,13 & 0,27 & $\mathbf{0 , 1 0}$ \\
\hline Kraśnicka (1) & $4 /-10,0$ & $-0,01$ & 4,03 & 0,28 & 0,12 & 0,18 & 0,06 & 0,20 & 0,08 \\
\hline Kraśnicka (1) & $1 /-4,6$ & $-0,20$ & 5,37 & 0,19 & 0,04 & 0,12 & $\mathbf{0 , 0 0}$ & 0,09 & 0,05 \\
\hline Kraśnicka (1) & $1 /-8,5$ & 0,09 & 3,13 & 0,39 & 0,19 & 0,22 & 0,15 & 0,29 & 0,11 \\
\hline Kraśnicka (1) & $1 /-9,9$ & $-0,49$ & 10,17 & $-0,01$ & $-0,14$ & $-0,08$ & 0,00 & 0,00 & 0,02 \\
\hline Kraśnicka (1) & $2 /-8,4$ & 0,22 & 5,63 & 0,18 & 0,03 & 0,11 & 0,00 & 0,08 & 0,05 \\
\hline Kraśnicka (1) & $2 /-9,5$ & 0,05 & 4,75 & 0,23 & $\mathbf{0 , 0 8}$ & 0,15 & 0,00 & 0,14 & 0,06 \\
\hline Kraśnicka (1) & $3 /-9,8$ & 0,01 & 6,20 & 0,15 & $\mathbf{0 , 0 0}$ & 0,09 & 0,00 & 0,04 & 0,04 \\
\hline Poligonowa(1) & $2 /-0,6$ & $-1,46$ & 3,40 & 0,34 & 0,17 & 0,21 & 0,12 & 0,26 & 0,10 \\
\hline Poligonowa(1) & $2 /-1,4$ & $-1,30$ & 3,43 & 0,33 & 0,17 & 0,21 & 0,12 & 0,26 & 0,10 \\
\hline Poligonowa(1) & $2 /-2,4$ & $-1,15$ & 4,77 & 0,23 & 0,08 & 0,15 & 0,00 & 0,14 & 0,06 \\
\hline Poligonowa(1) & $2 /-3,4$ & $-0,93$ & 4,80 & 0,23 & 0,07 & 0,15 & $\mathbf{0 , 0 0}$ & 0,13 & 0,06 \\
\hline Poligonowa(1) & $2 /-4,4$ & $-0,80$ & 6,17 & 0,15 & $\mathbf{0 , 0 0}$ & 0,09 & $\mathbf{0 , 0 0}$ & 0,04 & 0,04 \\
\hline Poligonowa(1) & $2 /-5,4$ & $-0,81$ & 7,47 & 0,09 & $-0,05$ & 0,04 & $\mathbf{0 , 0 0}$ & $\mathbf{0 , 0 0}$ & 0,03 \\
\hline Poligonowa(1) & $2 /-6,4$ & $-0,70$ & 8,27 & 0,05 & $-0,08$ & 0,00 & 0,00 & $\mathbf{0 , 0 0}$ & 0,03 \\
\hline Poligonowa(1) & $2 /-7,2$ & $-0,74$ & 6,97 & 0,11 & $-0,03$ & 0,06 & $\mathbf{0 , 0 0}$ & $\mathbf{0 , 0 0}$ & 0,04 \\
\hline Poligonowa(1) & $2 /-7,6$ & $-0,68$ & 6,83 & 0,11 & $-0,03$ & 0,06 & $\mathbf{0 , 0 0}$ & $\mathbf{0 , 0 0}$ & 0,04 \\
\hline Poligonowa(1) & $2 /-8,0$ & $-0,57$ & 7,40 & 0,09 & $-0,05$ & 0,04 & $\mathbf{0 , 0 0}$ & $\mathbf{0 , 0 0}$ & 0,03 \\
\hline Poligonowa(1) & $2 /-8,6$ & $-0,85$ & 9,77 & 0,00 & $-0,13$ & $-0,06$ & $\mathbf{0 , 0 0}$ & $\mathbf{0 , 0 0}$ & 0,02 \\
\hline Poligonowa(1) & $2 /-9,2$ & $-0,79$ & 7,47 & 0,09 & $-0,05$ & 0,04 & $\mathbf{0 , 0 0}$ & $\mathbf{0 , 0 0}$ & 0,03 \\
\hline Poligonowa(1) & $2 /-9,8$ & $-0,77$ & 6,70 & 0,12 & $-0,02$ & 0,07 & 0,00 & 0,01 & 0,04 \\
\hline Pana Balcera & $6 /-5,1$ & $-0,94$ & 8,50 & 0,04 & $-0,09$ & $-0,01$ & $\mathbf{0 , 0 0}$ & $\mathbf{0 , 0 0}$ & 0,03 \\
\hline Pana Balcera & $6 /-5,2$ & $-0,56$ & 8,30 & 0,05 & $-0,08$ & 0,00 & $\mathbf{0 , 0 0}$ & 0,00 & 0,03 \\
\hline Pana Balcera & $6 /-8,2$ & 0,29 & 3,83 & $\mathbf{0 , 3 0}$ & 0,14 & 0,19 & 0,08 & 0,22 & 0,08 \\
\hline Pana Balcera & $6 /-8,5$ & 0,47 & 3,58 & 0,32 & 0,16 & 0,20 & 0,10 & 0,24 & 0,09 \\
\hline Pana Balcera & $2 /-7,0$ & $-0,17$ & 3,47 & 0,33 & 0,17 & 0,20 & 0,12 & 0,25 & 0,10 \\
\hline Pana Balcera & $2 /-8,2$ & 0,06 & 4,43 & 0,25 & 0,10 & 0,16 & 0,00 & 0,16 & $\mathbf{0 , 0 7}$ \\
\hline Pana Balcera & $2 /-9,6$ & $-0,34$ & 5,70 & 0,17 & 0,02 & 0,11 & $\mathbf{0 , 0 0}$ & 0,07 & 0,05 \\
\hline
\end{tabular}

Bezpośrednim wynikiem sondowania statycznego są parametry oporu pod podstawą stożka $q_{c}$ oraz oporu na tulei ciernej $f_{s}$. Bazując na nich wyznacza się również współczynnik tarcia $R_{f}$, służący do klasyfikacji gruntu ze względu sposób zachowania. Przedstawione parametry są wartościami wyjściowymi na podstawie których wyznacza się parametry takie jak $I_{L}, I_{D}, E_{0}, M_{0}, \varphi, S_{u}$. Do ich obliczenia stosuje się wzory interpretacyjne wyznaczone na 
podstawie badań. Zazwyczaj jednak, wzory te skalibrowane są dla warunków lokalnych, występujących w obszarze prowadzonych badań.

Korelacja wtasna na podstawie badań laboratoryjnych.

Wykorzystując wyniki przeprowadzonych badań podjęto wstępną próbę wyznaczenia własnej formuły interpretacyjnej. W tym celu zestawiono na wykresach stopień plastyczności wyznaczony laboratoryjnie $\mathrm{z}$ oporami $q_{c} \mathrm{z}$ sondowania. Opory $q_{c}$ przyjmowano jako wartość średnią z zakresu głębokości $+/-20 \mathrm{~cm}$ pobrania próbki.

Przypadek 1. Zestawienie wyników wszystkich wartości $I_{L}$ przedstawiono na rysunku 7. Jak widać występuje znaczny rozrzut wyników. Należy zaznaczyć jednak, że dla większej części przebadanych próbek $I_{L}<0$, co jest zgodne z dotychczasową wiedzą, na temat naturalnej konsystencji lessów. Większość lessów okolic Lublina ma konsystencję zwartą.

Aby wyznaczyć zależność $q_{c} / I_{L}$, wyprowadzono dla niej wzory. Pierwszy wzór oszacowano przyjmując zależność liniową z wykorzystaniem metody najmniejszych kwadratów, natomiast drugi wzór wyprowadzono dla zależności logarytmicznej.

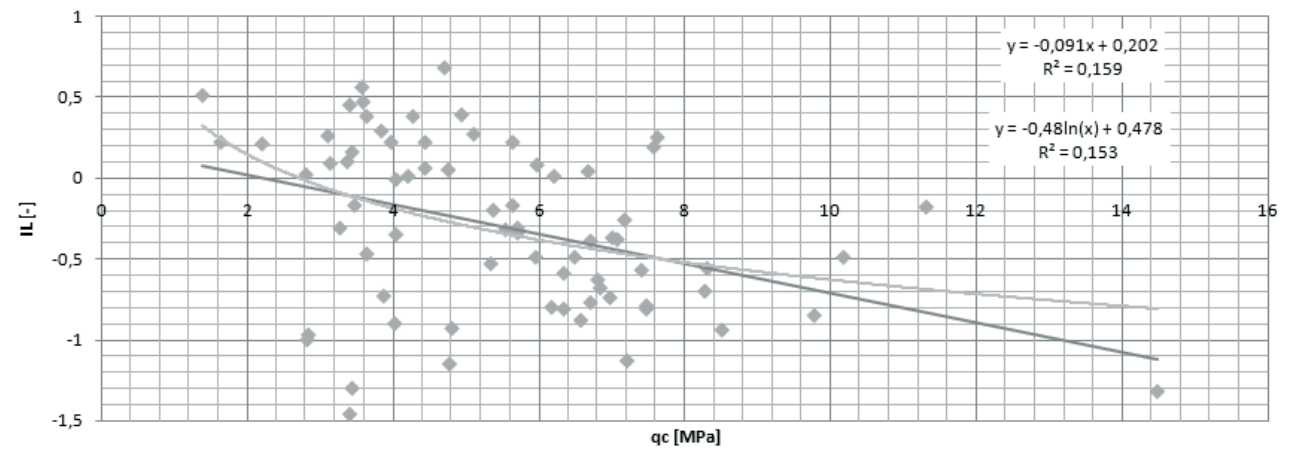

Rys. 7. Wykres zależności $I_{L}$ od $q_{c}-$ korelacja własna/przypadek 1

Otrzymano formuły zgodnie, z którymi $I_{L}<0$ osiąga się przy $q_{c}>2,71 \mathrm{MPa}$ dla zależności logarytmicznej oraz $q_{c}>2,22 \mathrm{MPa}$ dla zależności liniowej. Dla obu korelacji, współczynnik determinacji $R^{2}$ wynosi około 0,15 , co niestety jest dopasowaniem niezadowalającym.

Przypadek 2. W praktyce dla konsystencji „lepszych” niż twardoplastyczne nie wyznacza się dokładnego stopnia plastyczności, dlatego dla wartości $I_{L}<0$, przyjęto $I_{L}=0$ (Rys. 8). Takie działanie spowodowało „sztuczne pogorszenie” konsystencji gruntu oraz zmianę wzorów opisujących zależność $q_{c} / I_{L}$.

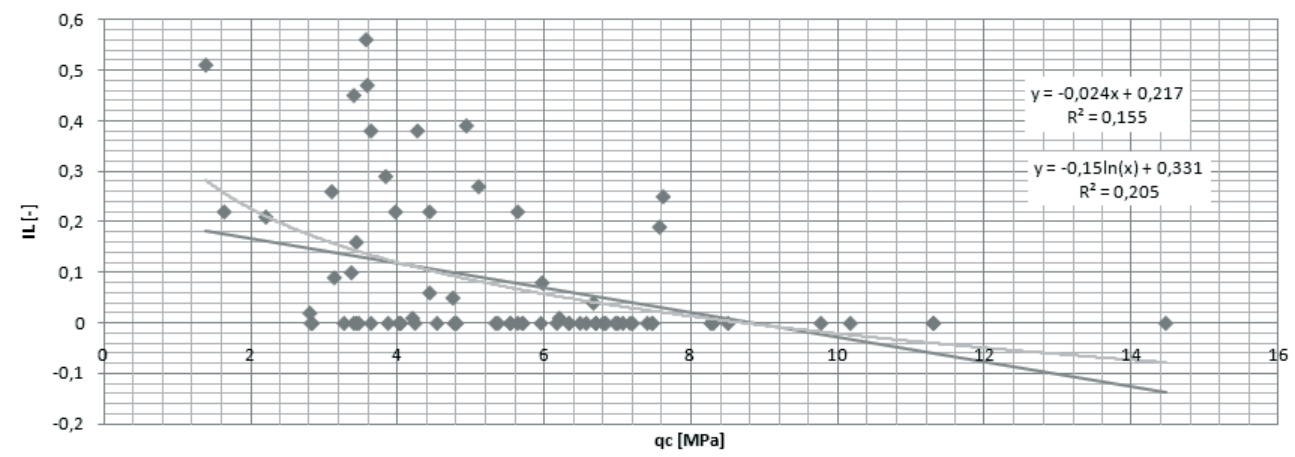

Rys. 8. Wykres zależności $I_{L}$ od $q_{c}$ - korelacja własna/przypadek 2. 
Według otrzymanych formuł $I_{L}$ osiąga wartości ujemne dla $q_{c}>8,61 \mathrm{MPa}$ dla zależności logarytmicznej oraz $q_{c}>8,87 \mathrm{MPa}$ dla zależności liniowej. Współczynnik determinacji $R^{2}$ wyniósł ok. 0,20 dla pierwszej formuły oraz ok. 0,16 dla drugiej, co jest dopasowaniem korzystniejszym niż w przypadku 1 , lecz nadal niezadowalającym.

Przypadek 3. Aby rozważyć sytuację pośrednią pomiędzy przypadkami 1 i 2 , w kolejnym kroku przyjęto graniczne minimum $I_{L}=-0,5$. Dla wartości mniejszych otrzymanych z badań, przyjęto wartość graniczną $I_{L}=-0,5$ (Rys. 9).

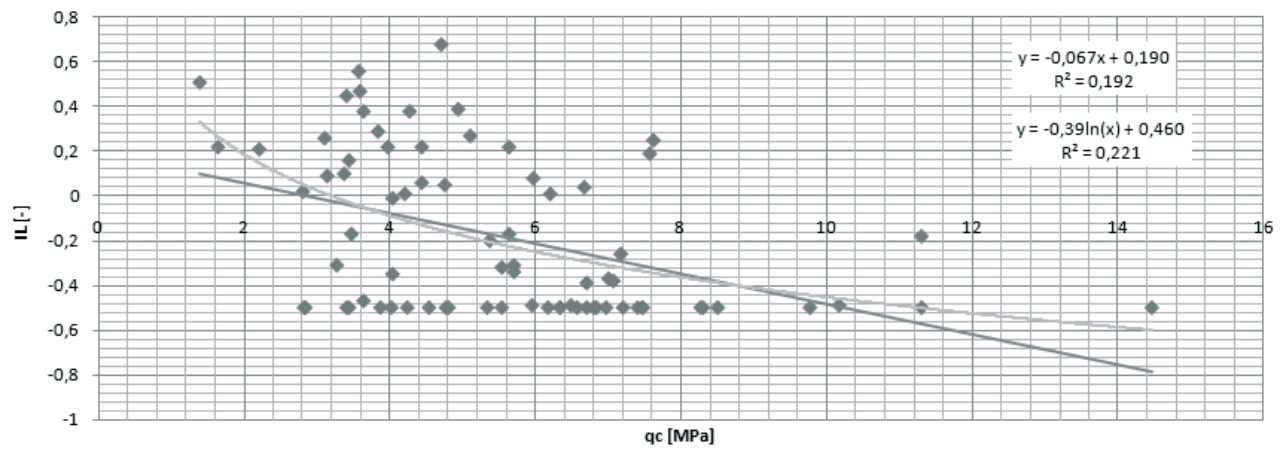

Rys. 9. Wykres zależności $I_{L}$ od $q_{c}-$ korelacja własna/przypadek 3

Z otrzymanych formuł wynika, że $I_{L}<0$ osiąga się przy $q_{c}>3,20 \mathrm{MPa}$ dla zależności logarytmicznej oraz $q_{c}>2,82 \mathrm{MPa}$ dla zależności liniowej. Współczynnik determinacji $R^{2}$ wyniósł ok. 0,22 dla pierwszej formuły oraz około 0,19 dla drugiej, co jest dopasowaniem korzystniejszym niż w przypadku 1 i 2, lecz nadal należy uznać je za niezadowalające.

Przypadek 4. W kolejnym kroku oszacowano zależności tylko na podstawie próbek o konsystencji twardoplastycznej lub „gorszej”, tj. dla których $I_{L}>0$ (Rys. 10).

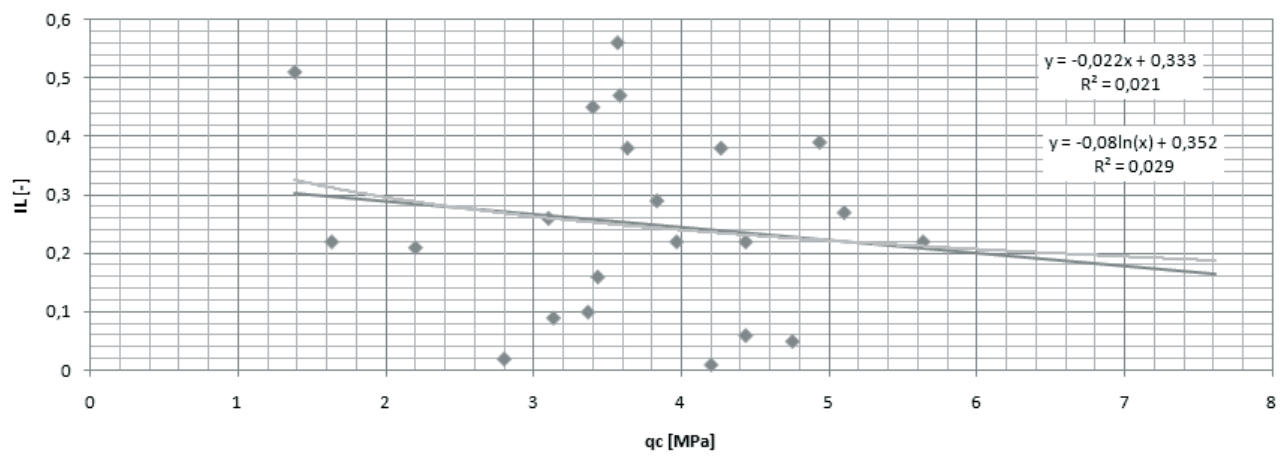

Rys. 10. Wykres zależności $I_{L}$ od $q_{c}-$ korelacja własna/przypadek 4

Otrzymano formuły, zgodnie z którymi $I_{L}<0$ osiągnięto przy bardzo dużych wartościach $q_{c}(78,01$ oraz 15,02$)$, co jest oczywiste (i nieprawdziwe) ze względu na przyjęte założenia wykorzystania tylko wyników dla których $I_{L}>0$. Współczynnik determinacji $R^{2}$ wyniósł jedynie około 0,02 dla pierwszej formuły oraz ok. 0,03 dla drugiej, co jest dopasowaniem nie do zaakceptowania. Dane takie można by uznać za przydatne, jedynie do wyznaczania $\mathrm{w}$ niewielkim przedziale i dla niskich wartości $q_{c}$. Formuła nie może służyć do wyznaczania $I_{L}<0$. 
Przypadek 5. Zmodyfikowano przypadek 4 dodając wyniki $I_{L}<0$, jednak tylko dla wartości $q_{c}>5 \mathrm{MPa}$ (Rys. 11). Próbki dla których $q_{c}<5 \mathrm{MPa}$, a $I_{L}<0$, odrzucono. Dla tych próbek, niewielki odpór $q_{c}$ prawdopodobnie wynika ze struktury gruntu i porowatości, a nie z konsystencji.

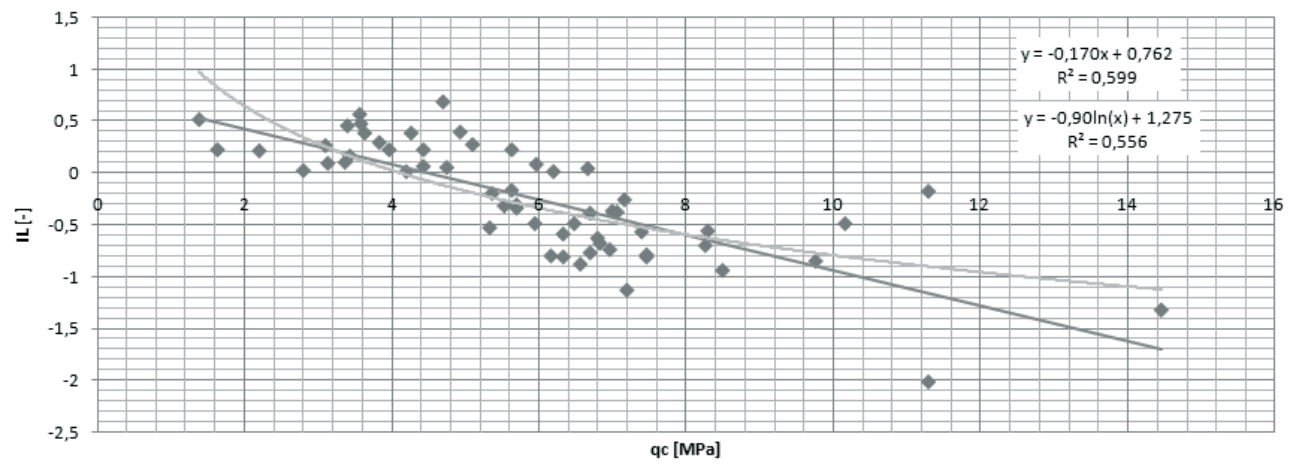

Rys. 11. Wykres zależności $I_{L}$ od $q_{c}-$ korelacja własna/przypadek 5

Otrzymano formuły zgodnie, z którymi $I_{L}$ przyjmuje wartości ujemne przy $q_{c}>4,12 \mathrm{MPa}$ dla zależności logarytmicznej oraz $q_{c}>4,47 \mathrm{MPa}$ dla zależności liniowej. Współczynnik determinacji $R^{2}$ wyniósł około 0,56 dla pierwszej formuły oraz około 0,60 dla drugiej, co jest dopasowaniem najlepszym z wszystkich dotąd wykonanych.

\section{Analiza wyników i wnioski}

Po analizie korelacji stopnia plastyczności wyznaczonego na podstawie badań laboratoryjnych z dostępnymi formułami stwierdzono, że najbardziej zbieżne wyniki otrzymano przy zastosowaniu ścieżki interpretacyjnej wg normy [8] dla gruntów o zawartości frakcji ilastej $10 \div 30 \%$ oraz według Wiłuna dla glin spoistych zwięzłych. Wprawdzie lessy są gruntami pylastymi, mało spoistymi o niewielkiej zawartości frakcji ilastej, jednak otrzymane wyniki jednoznacznie wskazują, że zaprezentowane formuły są najbardziej zbieżne z dostępnych, (szczególnie w zakresie wyższych wartości $q_{c}$ ). Dużym problemem w każdej z procedur jest wyznaczenie $q_{c}$, dla którego $I_{L}$ przyjmuje wartość poniżej zera. Zgodnie ze znanymi korelacjami, dla gruntów mało spoistych powinno to zachodzić przy stosunkowo dużej wartości $q_{c}$ (tj. dla $q_{c}>8 \div 9 \mathrm{MPa}$ ). Na podstawie wykonanych badań stwierdzono, że następuje to w granicach $4 \div 5 \mathrm{MPa}$. Z zaproponowanych własnych procedur, najwłaściwszą jest zależność liniowa z przypadku 5. Należy jednak dodać, że wyznaczona formuła ma charakter wstępny i będzie musiała zostać potwierdzona wynikami dalszych badań w celu rozbudowania bazy danych i weryfikację przyjętej interpretacji.

Dla wielu przebadanych próbek gruntów, pomimo niedużych wartości $q_{c}$, otrzymany z badań stopień plastyczności $I_{L}<0$. Świadczy to o tym, że dla podłoża lessowego nie tylko wilgotność i konsystencja mają wpływ na $q_{c}$, (a co za tym idzie na odkształcalność i wytrzymałość gruntu), ale również inne czynniki. Najprawdopodobniej do różnic w wartościach $q_{c}$ przyczyniają się porowatość, ułożenie, kształt i wielkość ziaren oraz spójność i kąta tarcia wewnętrznego. Biorąc pod uwagę, że większość lessów ma konsystencję zwartą, niezbędne jest wprowadzenie dodatkowych kryteriów wydzielania warstw geotechnicznych na cele projektowe. Analizując wyniki sondowań, można zauważyć, że dla gruntów zwartych, zakres oporów $q_{c}$ potrafi wynosić od 4 do nawet $11 \mathrm{MPa}$. W związku 
z tym, za parametr wiodący dla lessów, proponuje się przyjmowanie wartości $q_{c} \mathrm{z}$ sondowania statycznego, a nie jak to jest $\mathrm{w}$ zwyczaju $I_{L}$. Wydzielanie warstw geotechnicznych przyjmując tradycyjnie za parametr wiodący jedynie $I_{L}$, powoduje zaliczanie do jednej warstwy podłoża o znacząco różnej charakterystyce sztywności. Na rysunku 12 przedstawiono podział na warstwy geotechniczne wykonany na podstawie parametru wiodącego $I_{L}$ (Rys. 12a) oraz $q_{c}$ (Rys. 12b) jednej z lokalizacji. Zrealizowane badania potwierdzają taki stan w innych badanych miejscach. Projektowanie bez uwzględnienia różnorodności sztywności podłoża, może skutkować nierównomiernym osiadaniem budynku.

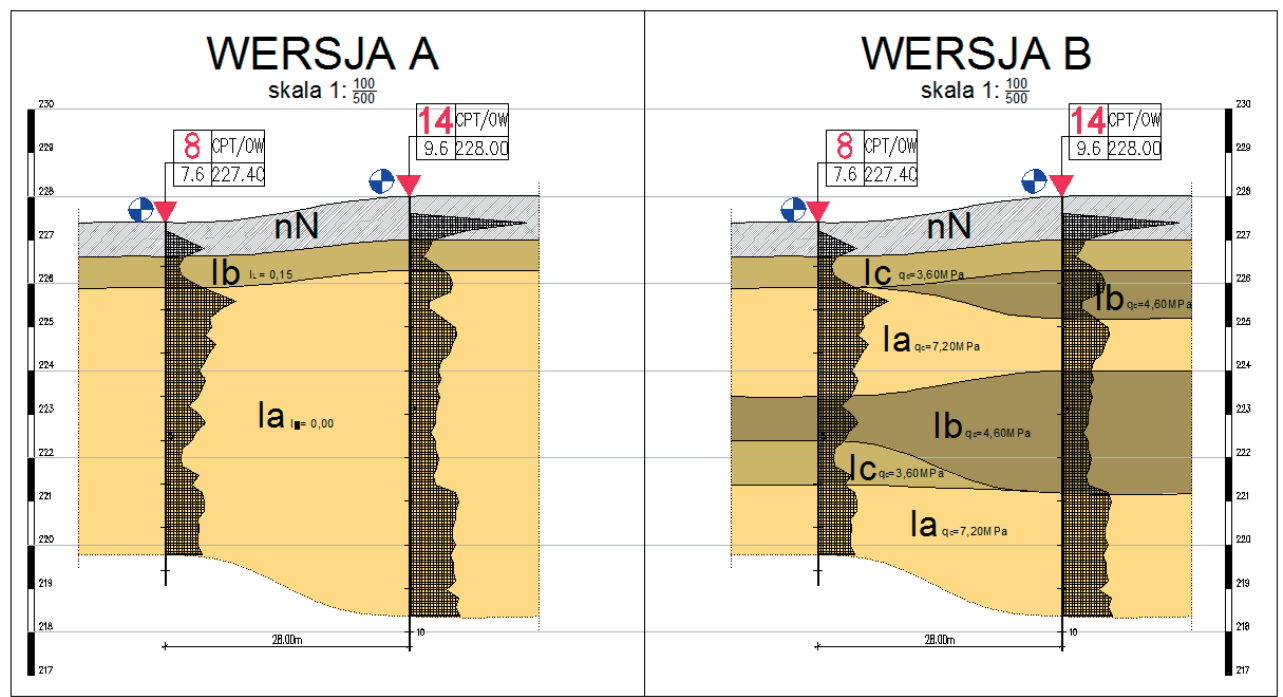

Rys. 12. Przekroje geotechniczne lessów a) parametr wiodący $-I_{L}$, b) parametr wiodący $-q_{c}$

W ramach dalszych badań autorzy planują zbieranie dodatkowych wyników badań do określania $I_{L}$ dla lessów $\mathrm{z}$ sondowania statycznego oraz opracowanie wytycznych do podziału na warstwy geotechniczne $\mathrm{z}$ wykorzystaniem $q_{c}$ jako parametru wiodącego.

\section{Literatura}

1 Maruszczak H. Definicja i klasyfikacja lessów oraz utworów lessopodobnych. Prz. Geol. 48 (2000) 580-586.

2 Malicki A. Geneza i rozmieszczenie lessów w środkowej i wschodniej Polsce (The origin and distribution of loess in Central and Eastern Poland). Ann. Univ. M.C.S. Sec. B, vol IV. Lublin; 1949.

3 Jahn A. Less, jego pochodzenie i zwiazek z klimatem epoki lodowej. Instytut Geograficzny Uniwersytetu Wrocławskiego, Wrocław; 1950.

4 Nowakowa B., Piotrowski S., Stefańska E. Badania geologiczne lessów. Wydawnictwa Geologiczne, Warszawa; 1971.

5 Grabowska-Olszewska B., Skeleted microstructure of loesses - its significance for engineering - geological and geotechnical studies. Apply Clay Science 4 (1989) 327-336.

6 Borecka A., Kaczmarczyk R. Geologiczno-inżynierska ocena zagrożén osuwiskowych w utworach lessowych poludniowo-wschodniej Polski, 2000. Geologos 11 (2007) 347-356.

$7 \quad$ PN-88 B-04481 Badania próbek gruntu.

8 PN-B-04452_2002 Geotechnika. Badania polowe. 
9 Wysokiński L., Kotlicki W., Godlewski T. Projektowanie geotechniczne wedtug Eurokodu 7. ITB, Warszawa 2011.

10 Wiłun Z. Zarys geotechniki. Wydawnictwa Komunikacji i Łączności, Warszawa; 2005.

11 Sikora Z. Sondowanie statyczne. Metody i zastosowanie w geoinżynierii. WNT, Warszawa; 2006.

\title{
The analysis of consistency evaluation of the loess in Lublin based on CPT tests
}

\section{Krzysztof Nepelski, Agnieszka Lal, Malgorzata Franus}

Department of Geotechnical Engineering, Faculty of Civil Engineering and Architecture, LublinUniversity of Technology,e-mail:k.nepelski@pollub.pl,a.lal@pollub.pl,m.franus@pollub.pl

\begin{abstract}
The paper presents the comparison of the laboratory results of the soil consistency with the results of static CPT tests. The study was carried out on the loess terrain in Lublin. The laboratory results were compared with the values estimated from the CPT tests based on the interpretation of various sources. The determination of an own interpretation formula was also undertaken. It was noticed that for the geotechnical division of the loess soil it is more accurate to use the $q_{c}$ value as the leading parameter, rather than the $I_{L}$ parameter as is the norm for cohesive soil. Given the possibility of obtaining more authoritative parameters determining the bearing capacity of the subsoil, the target is the recognition of the relation between the specified parameters.
\end{abstract}

Keywords: CPT tests, loess, the degree of plasticity, consistency, leading geotechnical parameter. 